\title{
Tinjauan Etika Penggunaan Media Sosial oleh Dokter
}

\author{
Pukovisa Prawiroharjo ${ }^{1,2}$, Nurfanida Librianty ${ }^{1,3}$
}

'Majelis Kehormatan Etik Kedokteran Pengurus Besar Ikatan Dokter Indonesia
${ }^{2}$ Departemen Neurologi, Fakultas Kedokteran Universitas Indonesia/Rumah Sakit Cipto Mangunkusumo, Jakarta 32Departemen Pulmonologi dan Kedokteran Respirasi, Fakultas Kedokteran Universitas Indonesia/Rumah Sakit Umum Pusat Persahabatan, Jakarta

\author{
Kata Kunci \\ media sosial; etika kedokteran \\ Korespondensi \\ pukovisa@ui.ac.id \\ contact@ilmiah.id \\ Publikasi \\ (C) 2017 JEKI/ilmiah.id \\ DOI \\ I0.26880/jeki.viir.7 \\ Tanggal masuk: 6 Juli 2017 \\ Tanggal ditelaah: 25 Juli 2017 \\ Tanggal diterima: 15 Agustus 2017 \\ Tanggal publikasi: II Oktober 2017
}

\begin{abstract}
Abstrak Penggunaan media sosial memberikan banyak manfaat bagi profesi dokter, antara lain memperluas jaringan profesi, membantu proses pendidikan profesi, mempermudah promosi fasilitas pelayanan kesehatan dan promosi kesehatan. Namun, penggunaan media sosial yang tidak bijaksana dapat menjadi menimbulkan masalah etik yang merusak reputasi profesi dokter. Masalah etik yang timbul akibat penggunaan media sosial oleh dokter umumnya disebabkan karena pelanggaran privasi pasien, ketidakjelasan batas hubungan antara dokter dengan pasien, pencemaran reputasi profesi, kualitas dan tingkat kepercayaan informasi yang kurang terjamin, serta pelanggaran aspek hukum. Mengingat kompleksitas masalah dan belum adanya aturan yang jelas di Indonesia tentang penggunaan media sosial oleh dokter, diperlukan kajian etik khusus untuk menyusun panduan penggunaan media sosial, baik untuk aktivitas personal maupun keperluan profesi dokter.
\end{abstract}

\begin{abstract}
The use of social media provides many benefits for medical profession, including expanding professional network, assisting the process of professional education, facilitate the promotion of health care facilities and health promotion. However, unwise use of social media can cause ethical problems which harm the medical profession. These ethical problems arising from doctor's use of social media are usually due to violation of patient's privacy, unclear boundary between physician-patient relationship, defamation, unassured quality and confidence level of information, and violation of legal aspects. Given the complexity of the problem and the absence of clear rules in Indonesia regarding the use of social media by physicians, special ethical studies are required to develop guidelines for doctor's use of social media, both for personal and professional needs of physicians.
\end{abstract}

\section{PENDAHULUAN}

Media sosial merupakan bagian tak terpisahkan dari kehidupan hampir seluruh lapisan masyarakat, termasuk kalangan dokter. Penggunaan media sosial di kalangan dokter cukup bervariasi, baik untuk aktivitas personal maupun keperluan profesi. Sebuah survei yang dilakukan pada 4.000 dokter di sebuah situs internet menunjukkan bahwa 90\% dokter menggunakan media sosial untuk aktivitas personal dan 65\% dokter menggunakan media sosial untuk keperluan profesi. ${ }^{1}$

Istilah "media sosial" memiliki pengertian luas dan terus berkembang. Secara umum, media sosial merupakan perangkat berbasis internet yang memudahkan individu atau komunitas tertentu untuk berkumpul dan berkomunikasi, serta berbagi informasi, ide, foto, dan konten lainnya. ${ }^{2-4}$ Terdapat beberapa jenis media sosial yang sering digunakan dokter, antara lain jejaring sosial (seperti Facebook), jejaring profesi (seperti LinkedIn), media sharing (seperti YouTube), dan content production (seperti Blog). ${ }^{3-5}$

Perilaku penggunaan media sosial untuk masyarakat Indonesia telah diatur dalam UndangUndang Nomor 11 Tahun 2008 tentang Informasi dan Transaksi Elektronik (ITE), di antaranya dilarang menyebarkan informasi yang menimbulkan kebencian pada suatu kelompok masyarakat berdasarkan suku, agama, ras, dan antargolongan (SARA), melakukan pengancaman atau pemerasan, penghinaan atau pencemaran nama baik, dan lainlain. Karena hal ini telah jelas diatur dalam undangundang, tulisan ini tidak membahas kembali hal tersebut. Namun, artikel ini bertujuan untuk membahas hal-hal yang belum diatur dalam ITE dan dapat berimbas pada profesi kedokteran.

Penggunaan media sosial untuk keperluan 
profesi dokter berperan dalam memperluas jaringan profesi, pendidikan profesi, promosi institusi, dan promosi kesehatan. ${ }^{4,6}$ Melalui media sosial, dokter dapat mempermudah pasien mengakses informasi kesehatan dan melibatkan masyarakat dalam diskusi mengenai kebijakan kesehatan., ${ }^{6,7}$ Selain itu, media sosial juga dapat memfasilitasi hubungan profesional tenaga kesehatan, baik dalam skala nasional maupun internasional. ${ }^{6}$

Dengan menggunakan media sosial, dokter dapat lebih mudah memberikan edukasi kepada pasien, keluarga pasien, dan teman sejawat. Penggunaan media sosial untuk kepentingan profesi dapat berdampak pada perluasan jaringan kolega dan peningkatan pemasukan dalam sektor kesehatan. ${ }^{4-7}$ Dalam pengembangan profesi, penggunaan media sosial membuat dokter lebih terbuka terhadap berita dan penemuan-penemuan baru di bidang kedokteran yang dapat meningkatkan wawasan. ${ }^{2}$

Meskipun membawa banyak manfaat dalam promosi dan layanan kesehatan, media sosial juga dapat membawa dampak negatif jika tidak digunakan secara bijaksana. Penggunaan media sosial yang sudah merebak menyebabkan penerapan hukum menjadi lebih kompleks. Beberapa hak konstitusional yang dapat diterapkan dalam penggunaan media sosial, antara lain kebebasan berbicara, kebebasan mencari, dan privasi, yang batasannya kini kerap kali menuai kontroversi. ${ }^{2}$ Beberapa masalah yang berkaitan dengan penggunaan media sosial oleh dokter umumnya disebabkan karena pelanggaran kerahasiaan pasien, ketidakjelasan batas hubungan antara dokter dengan pasien, pencemaran reputasi profesi, serta kualitas dan reliabilitas informasi yang kurang terjamin. ${ }^{2,8,9}$

\section{METODE}

Informasi dan data penunjang dikumpulkan melalui penelusuran literatur di basis data jurnal PubMed dan Annals of Internal Medicine, dengan kata kunci "social media", "doctors", dan "healthcare professionals"; situs web surat kabar daring Tempo. co Nasional dan Detiknews; situs web Kementerian Kesehatan Republik Indonesia, Ikatan Dokter Indonesia, Quantia MD Publication, General Medical Council, dan British Columbia Medical Journal Publication; Undang-Undang Republik Indonesia; serta Kode Etik Kedokteran Indonesia. Jurnal, artikel, dan regulasi yang digunakan sebagai dasar penulisan publikasi ini terbit antara tahun 2012-2017.

\section{HASIL DAN PEMBAHASAN}

\section{Isu Etik yang Timbul akibat Penggunaan Media Sosial oleh Dokter}

Masyarakat masih menghargai kehormatan profesi kedokteran, sehingga jika terdapat akun media sosial yang mencampurkan edukasi kedokteran masyarakat dengan kebebasan ekspresi pribadi, masyarakat berpotensi mempersepsikan kebebasan pribadi tersebut sebagai cerminan profesionalitas yang dimilikinya. Persepsi ini pun semakin rumit jika dokter yang terlibat merupakan pengurus teras dari suatu organisasi profesi, sehingga masyarakat dapat beranggapan bahwa pendapat pribadi dokter tersebut merepresentasikan pendapat organisasi profesi. Terlebih lagi, pada akun yang sudah dikhususkan untuk edukasi kesehatan yang mewakili profesi kedokteran, juga diperlukan pengkategorian informasi yang layak diakses masyarakat umum, ataukah lebih pantas informasi tersebut dikonsumsi di kalangan profesional dokter dan/atau tenaga medis secara terbatas. Untuk itu, diperlukan regulasi khusus penggunaan media sosial oleh dokter.

Perlu disayangkan adanya kasus seperti publikasi foto pasien saat operasi. Ikatan Dokter Indonesia (IDI) bahkan sempat memberi kecaman pada tenaga medis yang berfoto di tengah proses operasi pasien. $^{10}$ Informasi-informasi kesehatan yang disebarkan oleh orang yang tidak kompeten kini juga marak beredar di media sosial sehingga tak jarang menimbulkan kesalahpahaman dan sesat pikir. Oleh karena itu, dokter diperlukan untuk memonitor dan mengklarifikasi informasi tersebut berdasarkan sumber-sumber terpercaya yang dapat dipertanggungjawabkan. ${ }^{4,6,7}$

\section{Regulasi Penggunaan Media Sosial di Indonesia}

Secara umum, penggunaan informasi dan media elektronik telah diatur dalam UndangUndang Nomor 11 Tahun 2008 tentang Informasi dan Transaksi Elektronik. Mekanisme dan sanksi yang diterapkan pada pelanggaran hukum di media elektronik lebih dipaparkan jelas pada UndangUndang Nomor 19 Tahun 2016 yang memuat beberapa perubahan pada Undang-Undang Nomor 


\section{Tahun 2008. ${ }^{12,13}$}

Saat ini belum ada peraturan yang resmi mengatur penggunaan media sosial oleh dokter di Indonesia. Namun, para dokter diharapkan untuk menggunakan media sosial secara bijaksana dengan mempertimbangkan aspek-aspek etik yang termuat dalam Kode Etik Kedokteran Indonesia (KODEKI), terutama profesionalisme, keterangan dan pendapat yang valid, kejujuran, kebajikan sejawat, serta rahasia jabatan. ${ }^{11}$

\section{Regulasi Penggunaan Media Sosial oleh Dokter}

Di beberapa negara di Eropa, penggunaan media sosial oleh dokter telah diatur oleh General Medical Council (GMC) dalam sebuah publikasi berjudul "Doctor's use of social media" pada tahun 2013. Pada publikasi tersebut, GMC menegaskan bahwa dokter harus menjaga batasan dengan pasien, menjaga kerahasiaan rekam medik dan informasi pribadi pasien, menghindari pencemaran nama baik, serta menjaga rasa hormat terhadap sejawat. ${ }^{12}$

Disarankan agar dokter yang memiliki akun medial sosial membuat dua akun berbeda antara akunnya sebagai pemberi edukasi kesehatan (mewakili profesinya sebagai dokter), dan akun ekspresi pribadi. Menurut Budd, ${ }^{13}$ pada akun yang ditujukan untuk ekspresi pribadi, dokter perlu menolak pertemanan atau pemberian akses kepada pasien. Sedangkan, bagi akun yang dibuat untuk edukasi kesehatan, maka informasi yang layaknya terbatas pada kalangan profesional tidak boleh disampaikan pada media sosial yang tidak dapat atau minim diatur tingkat privasinya. Disarankan informasi ini disebarkan melalui jenis media sosial yang terenkripsi baik, sehingga sasaran dapat diatur secara tepat.

Untuk menghindari masalah etik yang timbul dari penggunaan media sosial oleh dokter, terdapat beberapa hal yang dapat dilakukan. Pertama, memperketat pengaturan privasi pegawai dan pasien di layanan kesehatan. Hal tersebut perlu dilakukan untuk mengetahui siapa saja yang mengakses konten yang dibuat atau disimpan oleh dokter. Meskipun terdapat pengaturan privasi, dokter dianjurkan untuk tetap waspada dengan ketidaksempurnaan sistem privasi di media sosial.

Selain itu, batasan antara dokter dengan pasien juga perlu diperjelas. Penetapan batasan tersebut dapat dilakukan dengan menghindari hubungan non profesional secara online dengan pasien, misalnya dengan membatasi pertemanan dengan pasien di situs profesi dan menolak pertemanan dengan pasien di situs pribadi. Ketika berbagi kasus secara online, dokter hendaknya menjaga kerahasiaan pasien dengan menghilangkan identitas pasien dan tetap meminta persetujuan pasien yang bersangkutan.

Pencemaran nama baik merupakan hal yang harus dihindari oleh dokter. Berdasarkan publikasi Budd, ${ }^{13}$ hukum pencemaran nama baik berlaku pada konten yang bersifat online. Oleh karena itu, dokter perlu berhati-hati dalam memberikan opini mengenai sejawat, pegawai, fasilitas pelayanan kesehatan, atau birokrasi kesehatan seperti dinas kesehatan, departemen kesehatan, dan Badan Penyelenggara Jaminan Sosial. Sebagai seorang dokter, mengevaluasi reputasi pribadi dan profesi secara berkala sangat penting untuk dilakukan. Evaluasi tersebut perlu dilakukan untuk memastikan informasi mengenai pribadi dan profesi dokter akurat dan layak terbit sehingga pencemaran nama baik yang mencoreng reputasi profesi dokter dapat dihindari.

Seorang dokter dituntut untuk jujur dalam berinteraksi secara online, termasuk dalam beriklan. Dokter hanya boleh beriklan secara online untuk layanan yang sah berdasarkan informasi yang terpercaya, akurat, dan relevan. Dokter tidak diperkenankan menggunakan testimoni pasien untuk mempromosikan diri.

\section{KESIMPULAN}

Aktivitas media sosial dari seorang Dokter memiliki potensi memberikan manfaat luas bagi masyarakat. Namun di sisi lain, dokter perlu menyadari bahwa aktivitasnya di media sosial harus juga memperhatikan nilai etika kedokteran. Dokter di samping taat kepada hukum yang mengatur aktivitas di media sosial juga perlu memperhatikan tujuan dan nilai etika yang melingkupinya dalam menjalankan aktivitas media sosial. Dokter harus dapat memilih jenis media sosial sesuai dengan tujuannya beraktivitas. Pada konten yang memerlukan batasan dan tidak untuk publik, disarankan Dokter menggunakan media sosial dengan tingkat privasi dan keamanan yang baik. Jika diperlukan, dokter dapat mengelola dua akun terpisah untuk tujuan edukasi kedokteran dan menyalurkan ekspresi pribadi. 
Fatwa Etika Kedokteran khusus mengenai pembatasan umum aktivitas media sosial oleh dokter sangat penting untuk dibuat segera untuk mengarahkan aktivitas media sosial oleh dokter menjadi produktif dan sesuai kaidah etika kedokteran Indonesia.

\section{KONFLIK KEPENTINGAN}

Tidak ada konflik kepentingan

\section{REFERENSI}

1. Modahl M, Tompsett L, Moorhead T. Doctors, patients \& social media [Internet]. 2011 Sep [disitasi 2017 Jul 1]. Diunduh dari: http:// www.quantiamd.com/q-qcp/social_media.pdf

2. Peck JL. Social media in nursing education: Responsible integration for meaningful use. J Nurs Educ. 2014;53(3):164-9. doi: 10.3928/0148483420140219-03.

3. Lambert KM, Barry P, Stokes G. Risk management and legal issues with the use of social media in the healthcare setting. J Heal Risk Manag. 2012;31(4):41-7. doi: 10.1002/jhrm.20103.

4. von Muhlen M, Ohno-Machado L.

Reviewing social media use by clinicians. J Am Med Inform Assoc. 2012;19(5):777-81. doi: 10.1136/ amiajnl-2012-000990.

5. George DR, Rovniak LS, Kraschnewski JL. Dangers and opportunities for social media in medicine. Clin Obstet Gynecol. 2013;56(3):45362. doi: 10.1097/GRF.0b013e318297dc38.

6. Househ M. The use of social media in healthcare: Organizational, clinical, and patient perspectives. Stud Health Technol Inform. 2013;183:244-8. doi: 10.3233/978-1-61499-203-5244.

7. Farnan JM, Sulmasy LS, Worster BK, Chaudhry HJ, Rhyne JA, Arora VM. Online medical professionalism: Patient and public relationships: Policy statement from the American College of physicians and the federation of State Medical Boards. Ann Intern Med. 2013;158(8):620-7. doi: 10.7326/0003-4819-158-8201304160-00100.
8. Pirraglia PA, Kravitz RL. Social media: New opportunities, new ethical concerns. Journal of General Internal Medicine. 2013;28(2):165-6.

9. Moorhead SA, Hazlett DE, Harrison L, Carroll JK, Irwin A, Hoving C. A new dimension of health care: Systematic review of the uses, benefits, and limitations of social media for health communication. J Med Internet Res. 2013;15(4):e85. doi: 10.2196/jmir.1933.

10. Mardiastuti A. IDI kecam tenaga medis yang selfie di tengah proses operasi pasien [Internet]. 2015 Dec 15 [disitasi 2017 Jul 1]. Diunduh dari: http://news.detik.com/berita/3096411/idi-kecamtenaga-medis-yang-selfie-di-tengah-proses-operasipasien

11. Majelis Kehormatan Etik Kedokteran Indonesia. Kode etik kedokteran tahun 2012. Jakarta; 2012.

12. General Medical Council. Doctors' use of social media [Internet]. 2013 Mar [disitasi 2017 Jul 1]. Diunduh dari: http://www.gmc-uk.org/ Doctors__use_of_social_media.pdf_51448306.pdf

13. Budd L. Physician tweet thyself: A guide for integrating social media into medical practice. B C Med J. 2013;55(1):38-41. 